J. Clin. Chem. Clin. Biochem.

Vol. 27, 1989, pp. 935-939

(C) 1989 Walter de Gruyter \& Co. Berlin - New York

\title{
Study of Bilirubin Binding in Human Serum by High-Performance Liquid Chromatography
}

\author{
By L. Soltés
}

Ústav experimentálnej farmakológie, Centrum fyziologických vied, Slovenská akadémia vied, Bratislava, Československo

\section{B. Sébille}

Laboratoire de Physico-chimie des Biopolymères, Centre National de la Recherche Scientifique, Thiais, France

\section{J.-P. Tillement}

Département de Pharmacologie, Faculté de Médecine, Université Paris - Val de Marne, Créteil, France and

D. Berek

Ústav polymérov, Centrum chemického výskumu, Slovenská akadémia vied, Bratislava, Československo

(Received May 2/August 7, 1989)

Summary: We describe a high-performance single-run liquid chromatographic method for the separation of protein-bound and "free" (loosely bound) bilirubin in human serum samples. The procedure is based on both the size-exclusion and the adsorptive properties of the column packing material, LiChrosorb Diol. The elution of all sample constituents is accomplished by means of an aqueous mobile phase containing a phosphatebuffered solution of human serum albumin or adult serum, supplemented by a small amount of bilirubin. The efficacy of the developed method is exemplified by assaying the bilirubin binding to human adult and infant sera.

\section{Introduction}

In $1979 L u$ et al. (1) reported a liquid chromatographic (HPLC) method for the fractionation of protein-bound and free bilirubin. In this method, a sample of serum, applied onto the HPLC column, packed with SynChropak GPC 100, is eluted with phosphate buffer $(0.01 \mathrm{~mol} / 1, \mathrm{pH} 7.4)$, and the effluent is monitored at $453 \mathrm{~nm}$. Protein-bound pigment passes unretained through the column, while free bilirubin, retained on the column, is released by subsequent repeated injections of a $0.1 \mathrm{mmol} / 1$ solution of bovine serum albumin in the eluent.

In the present work, bilirubin binding in human serum was studied by HPLC, using a solution of protein(s) plus a small amount of bilirubin as the mobile phase to release the pigment fraction that is otherwise trapped by the column filling material.

\section{Materials and Methods}

\section{Reagents}

Unhaemolysed adult serum (AS; $2.9 \mathrm{mg} / \mathrm{l}$ of total bilirubin), two different samples of infant serum (IS ${ }_{1}$ and $\mathrm{IS}_{2} ; 129$ and 102 $\mathrm{mg} / \mathrm{l}$ of total bilirubin, respectively), human serum albumin (No. A 1887, Sigma, St. Louis, MO, USA), bilirubin p.a. (Merck, Darmstadt, FRG), dithioerythritol 99\% (Aldrich-Europe, Beerse, Belgium), $\mathrm{KH}_{2} \mathrm{PO}_{4}$ p. a., and $\mathrm{Na}_{2} \mathrm{HPO}_{4} \times 12 \mathrm{H}_{2} \mathrm{O}$ p.a.

\section{Working solutions}

Bilirubin, $20 \mathrm{mg}$, was dissolved in $3 \mathrm{ml}$ of $\mathrm{NaOH}$ solution $(0.1$ $\mathrm{mol} / \mathrm{l}$ ) in a $10-\mathrm{ml}$ volumetric flask, followed by the addition of $30 \mathrm{mg}$ of dithioerythritol. The solution was adjusted to $10 \mathrm{ml}$ with phosphate buffer $(0.01 \mathrm{~mol} / \mathrm{l}, \mathrm{pH}$ 7.4). A blank working solution without bilirubin was prepared by the same procedure. Both working solutions were kept frozen until use. All manipulations involving bilirubin were performed in dim light. 
Mobile phase

A phosphate-buffered $(0.067 \mathrm{~mol} / \mathrm{l}, \mathrm{pH} 7.4)$ solution of I: human serum albumin $(80 \mathrm{mg} / \mathrm{l})$ or II: adult serum $(2 \mathrm{ml} / \mathrm{l})$, to which a small volume of the bilirubin working solution had been added (1000:0.05, v/v), was filtered through a Waters Assoc. ultrafilter membrane (porosity $0.45 \mu \mathrm{m}$ ) and immediately used as eluent. Redistilled water was used for the preparation of the phosphate buffer.

\section{Apparatus}

A Waters Assoc. pump (Model 6000 A solvent delivery system), a Rheodyne injection valve (Model 7120) equipped with a $10 \mu \mathrm{l}$ loop, and a Waters Assoc. photometric detector (Model 440) operated with a $436 \mathrm{~nm}$ filter were used for all the experiments. Separations were carried out at room temperature in a stainless steel column, $15 \mathrm{~cm} \times 4.7 \mathrm{~mm}$ (i. d.), packed with LiChrosorb Diol, mean particle size $5 \mu \mathrm{m}$ (Merck, Darmstadt, FRG). The mobile phase was pumped at a flow-rate of $1 \mathrm{ml} / \mathrm{min}$. The container bottle as well as the teflon tubings were wrapped in aluminum foil to protect the eluent from light.

\section{Samples}

Samples for analysis were prepared freshly by appropriately mixing the two working solutions with serum. In the set assayed, with the samples coded $a-m$, the dilution factor of serum was 0.6. A $10-\mu \mathrm{l}$ sample thus contained $6 \mu \mathrm{l}$ of serum and $4 \mu \mathrm{l}$ of a diluent. Dilutions were performed to obtain the following concentrations of exogenous bilirubin: $0,0.0625,0.125,0.1875$, $0.25,0.3125,0.375,0.5,0.625,0.75,1,1.5$, and $2 \mathrm{~g} / \mathrm{l}$.

\section{Results}

The HPLC elution profiles of the assayed set of adult serum samples obtained with eluent $I$ are shown in figure 1. The chromatogram of the diluted serum sample containing no exogenous bilirubin (fig. 1, a) shows two peaks. The HPLC analysis of samples containing exogenous bilirubin showed (see fig. 1, $b-m)$ that small amounts of added pigment were preferentially bound to the protein with longer retention time, while at higher concentrations of exogenous bilirubin protein with shorter retention time became pronouncedly stained and, moreover, a plateau at the higher retention time kept expanding.

Figures 2 and 3 show the results obtained by assaying the bilirubin binding to two different samples of infant serum $\left(\mathrm{IS}_{1}, \mathrm{IS}_{2}\right.$ ) using eluent II. (The sample $\mathrm{IS}_{2}$ with a lower total bilirubin level came from the group of infants whose hyperbilirubinaemia was less physiological than that in another group.) The chromatogram of the diluted $\mathrm{IS}_{1}$ sample containing no exogenous bilirubin (see fig. 2, a) showed only one peak. The ability of the other, the less retained protein to bind bilirubin was confirmed at relatively high levels of the exogenous pigment (cf. fig. 2, i-m). Likewise, the results of the HPLC analysis of sample $\mathrm{IS}_{2}$ (see fig. 3) imply that endogenous bilirubin as well as all additional exogenous pigment is partitioned nearly

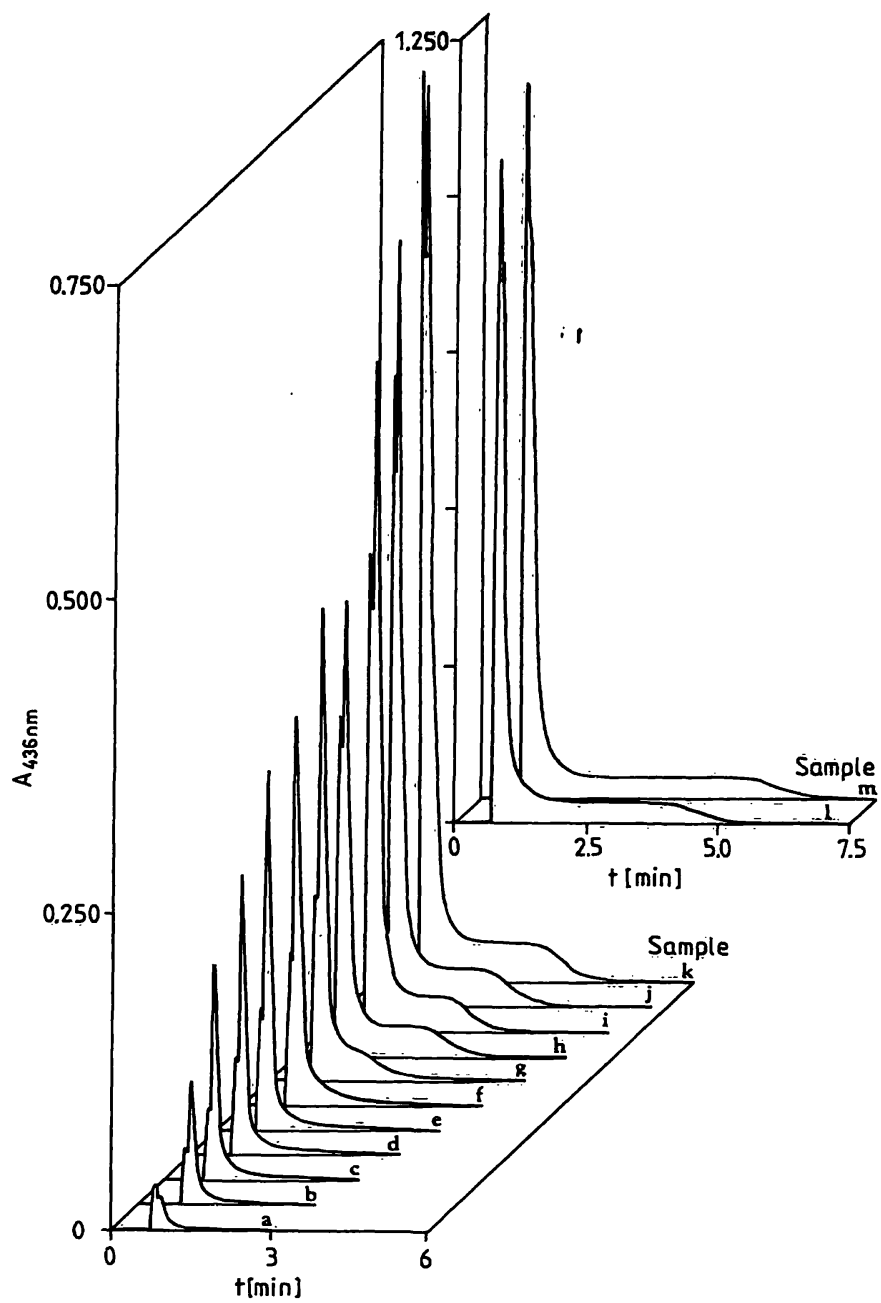

Fig. 1. HPLC elution profiles of the assayed set of adult serum (AS) samples $a-m$.

The actual level of total bilirubin in samples $\mathrm{a}-\mathrm{m}$ was $1.74,26.74,51.74,76.74,101.74,126.74,151.74,201.74$, $251.74,301.74,401.74,601.74$, and $801.74 \mathrm{mg} / \mathrm{l}$, respectively. (During the analysis of the samples coded $a-k$ the attenuation of the detector was set to 1 , while the recording of the samples coded 1 and $m$, shown in the upper right corner of the panel, was obtained at attenuation 2.)

equally between the two serum proteins. Unlike adult serum, the HPLC analysis of both infant serum samples revealed the presence of a plateau even in the absence of the exogenous pigment (see figs. 2, a, and 3 , a). It should be noted that the actual level of total bilirubin in the samples coded $\mathrm{c}$ and $\mathrm{d}$ of the set of bilirubin containing AS samples (51.74 and 76.74 $\mathrm{mg} / \mathrm{l})$ is virtually the same as the level in the sample coded a of the IS $_{1}(77.4 \mathrm{mg} / \mathrm{l})$ or IS $_{2}(61.2 \mathrm{mg} / \mathrm{l})$ samples.

The within-day repeatability of the developed chromatographic method was determined from the area under the HPLC record for samples containing 200 $\mathrm{mg} / \mathrm{l}$ of exogenous bilirubin (samples coded $\mathrm{h}$ ). Coefficients of variation from quadruplicate determinations were: $2.2 \%$ and $1.3 \%$ for the AS sample using eluents I and II, respectively; and $2.2 \%$ and $3.6 \%$ for $\mathrm{IS}_{1}$ and $\mathrm{IS}_{2}$, respectively, using eluent II. 


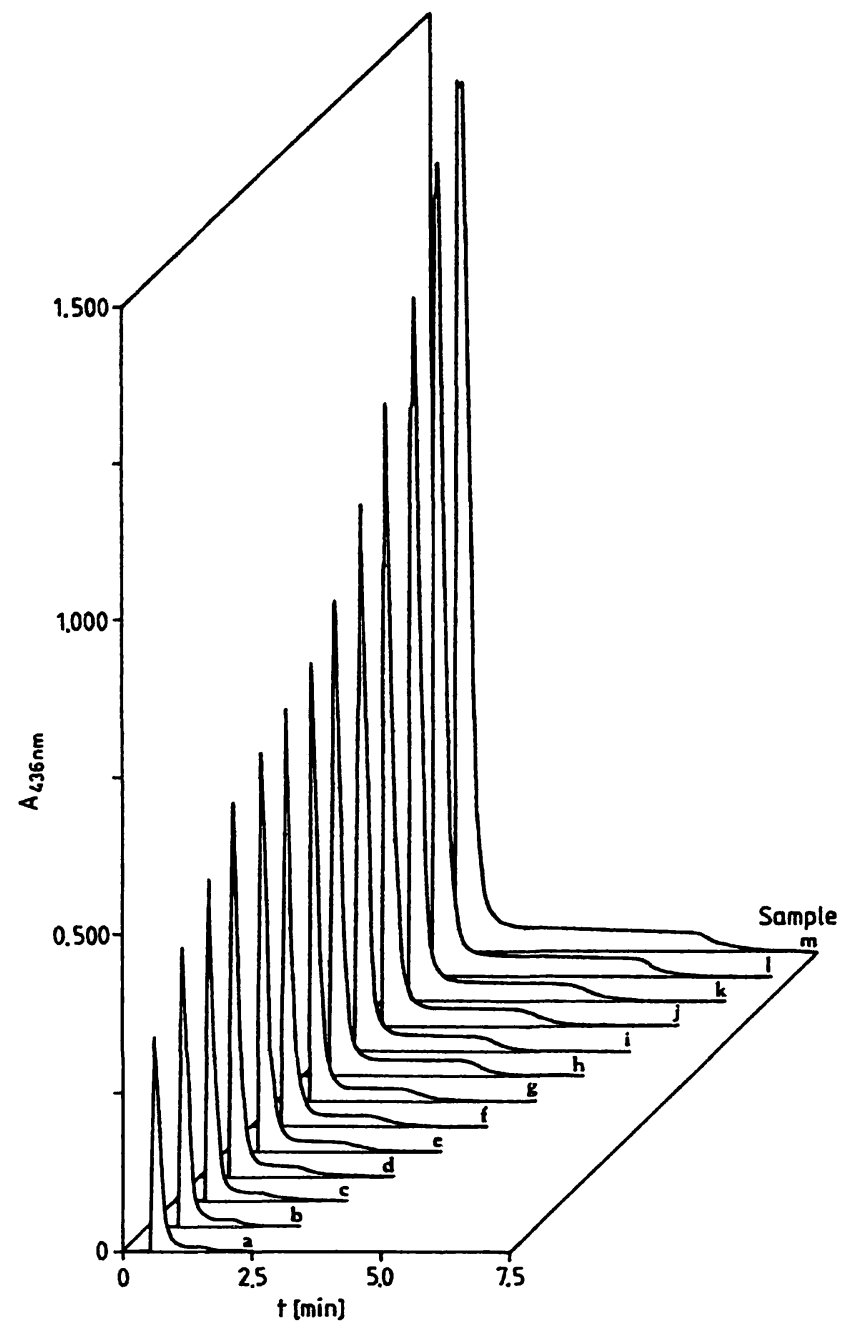

Fig. 2. HPLC elution profiles of the assayed set of infant serum $\left(\mathrm{IS}_{1}\right)$ samples $\mathrm{a}-\mathrm{m}$.

The actual level of total bilirubin in samples $\mathrm{a}-\mathrm{m}$ was $77.4,102.4,127.4,152.4,177.4,202.4,227.4,277.4$, $327.4,377.4,477.4,677.4$, and $877.4 \mathrm{mg} / 1$, respectively.

\section{Discussion}

This study was initiated by investigating the ability of phosphate-buffered $(0.067 \mathrm{~mol} / \mathrm{l}, \mathrm{pH} 7.4)$ solutions of human serum albumin $(40-400 \mathrm{mg} / 1$ of protein) to elute bilirubin from the column. At the highest protein concentration $(400 \mathrm{mg} / \mathrm{l})$ in the eluent, the bilirubin of adult serum samples was totally eluted in a single peak, whereas at the lowest albumin concentration (40 $\mathrm{mg} / \mathrm{l})$, the free (loosely bound) bilirubin fraction was trapped by the column filling material. According to $L u$ et al. (1) this fraction of bilirubin can be fully recovered from LiChrosorb Diol simply by means of several injections of e.g. the eluent with the highest albumin concentration.

In the next step, the effect of bilirubin added to the eluent was studied on the HPLC elution patterns. On the basis of these experiments it can be concluded that the addition of bilirubin to the mobile phase resulted in an improved symmetry of the peak(s) as

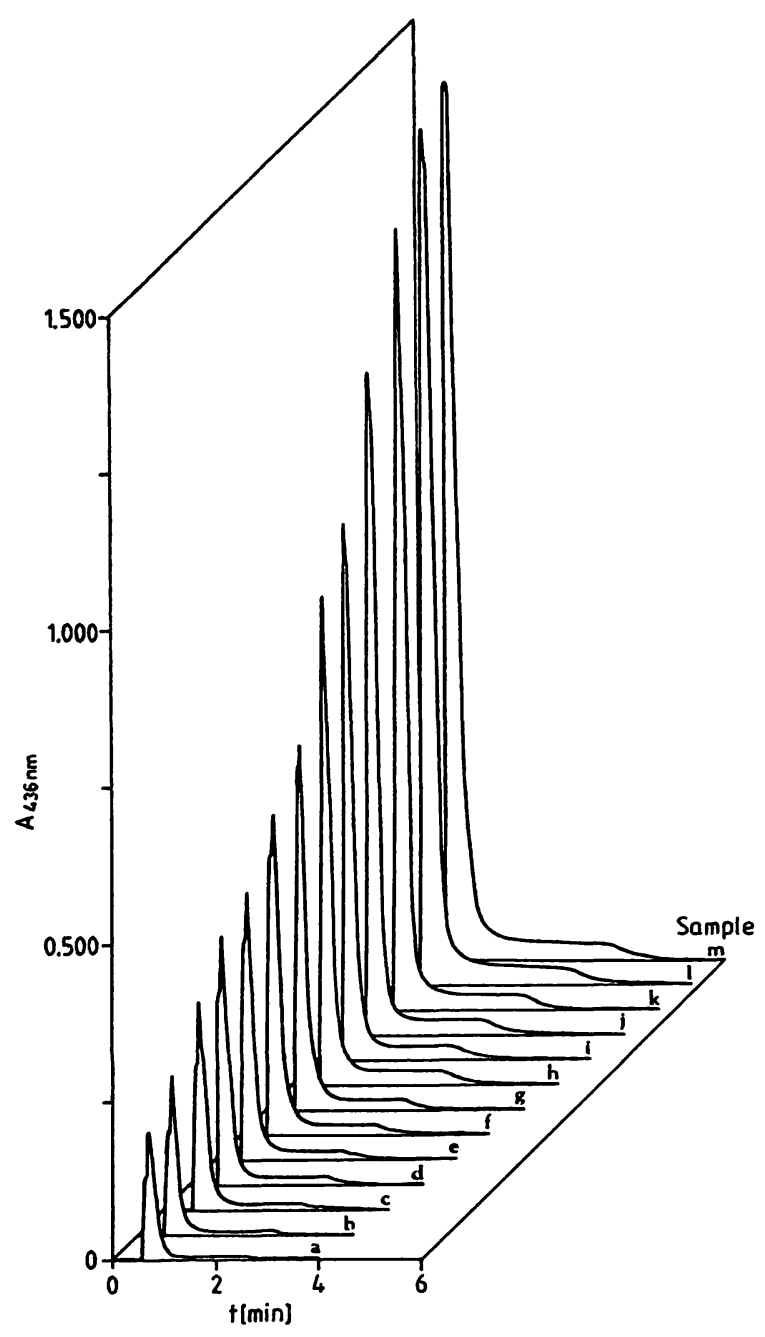

Fig. 3. HPLC elution profiles of the assayed set of infant serum $\left(\mathrm{IS}_{2}\right)$ samples $\mathrm{a}-\mathrm{m}$.

The actual level of total bilirubin in samples $\mathrm{a}-\mathrm{m}$ was $61.2,86.2,111.2,136.2,161.2,186.2,211.2,261.2,311.2$, $361.2,461.2,661.2$, and $861.2 \mathrm{mg} / \mathrm{l}$, respectively.

well as a suppression of the drift of the baseline between HPLC runs. By using the phosphate buffered human serum albumin solution of $80 \mathrm{mg} / \mathrm{l}$ mixed with the bilirubin working solution in the volume ratio of 1000: 0.05 (eluent I), we were able to resolve, in one single run, each bilirubin fraction in samples of human serum.

Comparison of the results given in figure 1 with those reported by Cooke \& Roberts (2) shows an excellent agreement. These authors studied the distribution of bilirubin in serum proteins separated on Sephadex G100 , by monitoring the UV/VIS light absorption of the effluent. They passed diluted adult sera containing exogenous bilirubin through the column eluted with phosphate buffer $(0.067 \mathrm{~mol} / \mathrm{l}, \mathrm{pH} 7.4)$, and obtained two peaks of protein-bound bilirubin. The leading peak was $\beta$-lipoprotein-bilirubin associate, and the other peak was the albumin-bilirubin complex. Re- 
peated applications of each individual fraction separately to the columns of Sephadex G-100 showed different abilities of the two proteins to bind bilirubin. When the stained $\beta$-lipoprotein was run through the column a pigment trail remained, but this behaviour was not shown by the albumin containing fraction. It was found that the pigment remaining inside the column could be eluted with additional serum. These experiments suggest that Sephadex G-100 competes for bilirubin by an active adsorption effect and that the complex of the pigment with lipoprotein is less stable than that with albumin.

Phenomena similar to those reported by Cooke \& Roberts (2) could be assumed to be present in our experimental setting, since attraction between $\mathrm{Li}$ Chrosorb Diol and protein(s)-bilirubin complexes can be expected (see fig. 1). Therefore, under our experimental conditions (eluent I), the distribution of exogenous bilirubin between the two proteins, as well as the amount of the loosely bound (dissociable) pigment fraction can be determined during one single chromatographic run. The relatively constant height of the plateau observed on the HPLC elution profile of the samples coded $\mathrm{h}-\mathrm{m}$ (cf. fig. $1, \mathrm{~h}-\mathrm{m}$ ) is most probably maintained by the reserve albumin binding capacity of the eluent I. By using this mobile phase the fraction of bilirubin retarded by LiChrosorb Diol is released, due to the affinity of the pigment for the unoccupied binding sites of albumin in the eluent.

Replacement of human serum albumin in the mobile phase by adult serum $(2 \mathrm{ml} / \mathrm{l})$ (i.e. the use of eluent II) did not markedly influence the character of the HPLC elution profile of the assayed adult serum samples; chromatograms showed a similar superposition of peaks and plateaus. The observed slightly diminished resolution of individual serum proteins stained with bilirubin (not shown) with eluent II can be accounted for by the blockade of LiChrosorb Diol pores with constituents of the mobile phase. However, the use of such a multicomponent mobile phase caused a significant suppression of the liberation (dissociation) of the pigment from the protein(s)-bilirubin complexes due to its adsorption to LiChrosorb Diol. That is why eluent II was preferred for assaying the infant serum samples $\left(\mathrm{IS}_{1}, \mathrm{IS}_{2}\right)$.

To clarify the origin of the peaks and plateau on the chromatograms of $\mathrm{IS}_{1}, \mathrm{IS}_{2}$ and AS, the phosphatebuffered $(0.067 \mathrm{~mol} / \mathrm{l}, \mathrm{pH} 7.4)$ solutions of human serum albumin $(40 \mathrm{~g} / \mathrm{l})$, diluted $(6: 4, \mathrm{v} / \mathrm{v})$ with the given set of the exogenous bilirubin diluent (see Materials and Methods; "Samples"), were run through the HPLC assay using eluents I and II. The elucidation of the HPLC behaviour of bilirubin-stained $\beta$ lipoprotein samples is limited, since the pure protein is not commercially available. It would be possible to use the commercially available fraction of low density lipoproteins, which contains the $\beta$-lipoprotein in question, but this has not been tried in the present study. In chromatograms of human serum albumin samples stained with a sufficient amount of bilirubin (samples $d-m$ using eluent II, $c-m$ using eluent $I$ ), the peak and plateau are superimposed (not shown). The chromatographic peak-plateau pattern of the bilirubin stained human serum albumin samples $(\mathrm{d}-\mathrm{m})$ closely resembled the pattern of $I S_{1}$ samples $(a-b)$. Therefore the other peak, which precedes the albumin and is seen in e. g. HPLC separations of heavily stained IS $_{1}$ samples (see fig. $2, i-m$ ), might originate from the stained $\beta$-lipoprotein. Such a statement can so far be supported only indirectly by taking into account the size-exclusion properties of the used LiChrosorbDiol and the substantially higher molecular weight $\beta$-lipoprotein as compared with that of albumin.

Assuming that bilirubin bound to $\beta$-lipoprotein and to albumin, and bilirubin liberated (dissociated) from these two proteins to be the origin of the peaks and plateau, respectively (figs. 1-3), the results of the HPLC analysis of the samples AS, IS $_{1}$ and IS $_{2}$ can be evaluated as follows.

a) Sample AS is the serum of a healthy adult. The peaks on the chromatogram of the diluted native serum (fig. 1, a) represent all light (over $436 \mathrm{~nm}$ ) absorbing serum components, i. e. bilirubin-stained $\beta$ lipoprotein and albumin, as well as oxyhaemoglobin, transferrin, carotenoids, etc. The exogenous pigment, added in gradually increasing amounts, was first (fig. $1, b-g$ ) bound primarily by albumin due to its higher binding capacity for bilirubin compared with that of $\beta$-lipoprotein. After albumin has bound a certain quantity of bilirubin, $\beta$-lipoprotein becomes increasingly involved in binding the exogenous pigment, since in these heavily loaded serum samples its binding capacity was comparable (cf. fig. $1, \mathrm{~h}-\mathrm{j}$ ) or even greater (cf. fig. 1, $\mathrm{k}-\mathrm{m}$ ) than the "reserve" bilirubin binding capacity of albumin. Simultaneously; part of the loosely bound (dissociable) pigment was adsorbed by LiChrosorb Diol, yet continuously flushed off by the protein(s)-containing eluent (cf. fig. 1, g-m).

b) Sample $I_{1}$ is the serum of a hyperbilirubinaemic infant. The chromatogram of the diluted native serum (fig. 2, a) reveals that the albumin loses part of the bilirubin owing to the competitive affinity of the ad- 
sorbent for the pigment. This probably happens because the albumin is a less mature form compared with that in sample AS. The load of further amounts of exogenous pigment was also proportionally partitioned between albumin and LiChrosorb Diol (cf. fig. $2, b-h) . \beta$-Lipoprotein became stained only after a relatively high pigment load (cf. fig. $2, \mathrm{i}-\mathrm{m}$ ). The very low bilirubin binding capacity of $\beta$-lipoprotein in this serum sample may also be due to the relatively very low level of this protein in $\mathbf{I S}_{1}$.

c) Sample $\mathrm{IS}_{\mathbf{2}}$ is the serum of another hyperbilirubinaemic infant. The chromatogram of the diluted native serum (fig. 3 ,a) reveals that both proteins participated in the binding of endogenous bilirubin in this sample. This may be accounted for by the relatively low binding capacity of albumin (more immature albumin than in sample $I_{1}$ ), and also by increased bilirubin binding by possibly higher level of $\beta$-lipoprotein in the sample. Further increases in the amount of exogenous pigment led to its extra and equal binding by the two bilirubin-binding proteins. Apart from indirect speculative considerations, no conclusive explanation can be provided for the clearly different shape of the plateau on the IS $_{2}$ chromatograms compared with the plateau from serum $\mathrm{IS}_{1}$ and AS (cf. fig. 3 vs. figs. $2(1)$ ).

\section{References}

1. Lu, K.-C., Gooding, K. M. \& Regnier, F. E. (1979) Rapid analysis of bilirubin in neonatal serum. I. The binding of bilirubin to albumin. Clin. Chem. 25, 1608-1612.

2. Cooke, J. R. \& Roberts, L. B. (1969) The binding of bilirubin to serum proteins. Clin. Chim. Acta 26, 425-436.
Clinical studies are necessary to assess the extent to which the elution pattern from this HPLC assay (figs. 2 and 3) can reflect the risk of infant hyperbilirubinaemia turning into a pathological condition.

\section{Conclusion}

The HPLC assay described here provides a powerful tool for the determination of "free" and proteinbound bilirubin fractions in a sample of human serum. The distribution of endo- and exogenous bilirubin between albumin and $\beta$-lipoprotein is clearly detectable even in a minute volume of serum.

Since both alteration of the albumin ability to bind bilirubin and sudden changes in the level of serum lipoproteins (3) occur frequently during the postnatal period, the assay could be used to advantage particularly in paediatrics.

\section{Acknowledgement}

The author L. S. is very grateful to the University of Paris Val de Marne, and to the Scientific Exchange Agreement Foundation Hamilton, for supporting his study stay at the Laboratory of Physical Chemistry of Biopolymers, U.E. R. of Sciences, and at the Department of Pharmacology, Faculty of Medicine, Créteil.

3. Kirstein, D., Johansen, K. B., Petersen, M. B. V. \& Andersen G. E. (1985) Changes in plasma lipoproteins from first day to third week of life in healthy breast-fed infants. I. Lipid and protein composition of lipoproteins. Acta Paediatr. Scand. 74, 733-737.

Dr. L. Šoltés

Institute of Experimental Pharmacology Centre of Physiological Sciences

Slovak Academy of Sciences CS-84216 Bratislava 


$$
\text { - }
$$

